Warszawskie Studia Pastoralne UKSW

Rok XI 2016 Nr 4(33)

Zofia KęPIŃSKa-WALCZAK

\title{
ABORTION: A THREAT OF MODERN TIMES
}

"Before I formed you in the womb I knew you; before you were born I consecrated you" (Jer 1: 5)

There is no explainable reason that would give a man the right to decide on the life and death of the other. There is no reason why one life should be considered less valuable and less worthy than the other. Finally, there is no logical justification for treating the possibility to decide on someone's life and death as an individual right, derived from the principle of human freedom. There should be no consent to such a tendency. Unless we want to lose our humanity, we must always keep this in mind: it is not in our hands to decide on the beginning or end of human life. If we do not respect this rule, we will cut off the branch on which we are sitting. Then, we will acknowledge that the value of our lives depends on the evaluation of others and is subject to debate. And the Church teaches, "human life must be respected and protected absolutely from the moment of conception. From the first moment of his existence, a human being must be recognized as having the rights of a person - among which is the inviolable right of every innocent being to life"1. Abortion is precisely this kind of threat which in its roots questions the value of human life. Let us first describe what abortion is.

1 Catechism of the Catholic Church, no. 2270. 


\section{What is abortion and what are its consequences?}

Abortion is the termination of pregnancy, i.e. the ending of human life at its very beginning. Today, pro-abortion organizations are trying to convince us that abortion is not murder, but only surgery eliminating the problem of unwanted pregnancy. Speaking of an unborn human being, they avoid the word "child", bringing the human being down to some unspecified organism, agglomerate of cells and tissues, "something" that is not a human being, but will become a human being immediately at birth. There is a certain paradox in the abortionists' logic. In many countries, man is not considered a human being at the moment of conception, but, at the same time, the law allows inheritance by a conceived but unborn child. Abortionists deny themselves in their theories. In their opinion, a child killed in the fifth month of pregnancy is not a human being, but the one born at this stage as premature, already is.

Powerful organizations that describe themselves as defenders of women's rights are for the legalization of abortion. They acknowledge the possibility that a woman can terminate the life of her own child. There has been a known case of Alicja Tysiąc, who, after being refused to perform abortion, filed a complaint about the Republic of Poland to the European Court of Human Rights. Alicja Tysiąc was awarded compensation in the amount of 25000 Euro. However, members of the Court were not unanimous in this case. Judge Francisco Javier Borrego filed a dissenting opinion, which stated that "all human beings are born free and equal in their rights and dignity. Today the Court has decided that a human being was born as a result of a violation of the European Convention on Human Rights. According to this reasoning, there is a Polish child, currently six years old, whose right to be born contradicts the Convention. I would never have thought that the Convention would go so far, and I find it frightening"2.

To pro-abortion organizations, Alicja Tysiąc became an icon of the martyr fighting for the rights of women, the right to "decide about

\footnotetext{
2 After: http://gosc.pl/doc/767838.Przyzwoity-sedzia-ze-Strasburga (February 14, 2016).
} 
their own belly". Tysiąc's argument for performing an abortion was the negative impact of pregnancy on her health, especially her eyes ${ }^{3}$. It is significant that, according to experts' opinions, pregnancy and childbirth did not affect the deterioration of her eyesight. Unfortunately, organizations supporting abortion are reluctant to talk about the negative impact of abortion on the mental and physical health of women, or even about a proven threat it poses to a woman's life. After such a brutal interference, the mother's body is exposed to a number of negative consequences which may lead to death. A woman may have trouble becoming pregnant again, or may even become infertile after abortion. We should also look at the psychological condition of women. Almost every woman feels more or less remorse, anxiety, grief - these are only the mildest effects of abortion on women's psyche. Depression, bouts of anxiety and aversion to life are frequent negative psychological effects of abortion. While many women choose to have an abortion because they lack the support or presence of an unborn child's father, we cannot marginalize the role of the father. $\mathrm{He}$ often participates in the decision to perform abortion; together with the woman, he bears full responsibility and experiences the effects of abortion. A large percentage of marriages that have decided to terminate the life of their unborn child disintegrates. The meaning of marriage becomes distorted, as marriage, by its nature, is open to the acceptance of a child - the fruit of love between a man and a woman. How, then, can a marriage continue to function having rejected this fruit? It could be argued that such a marriage has, in fact, no further reason to exist. Man is created out of God's love, and man himself is called to love. This is man's fundamental vocation. In his encyclical Humanae vitae, Paul VI emphasizes that God instituted marriage

3 "Alicja Tysiąc was awarded compensation in the amount of 25000 Euro in respect of non-pecuniary damage caused by a violation of the Convention. However, because of the opinions of experts who believe that pregnancy and childbirth did not affect the deterioration of Alicja Tysiąc's eyesight, the Court dismissed the claim for compensation for health deterioration (paragraph 151 of the judgment)." (source: https://pl.wikipedia.org/wiki/Wyrok_Europejskiego_Trybuna\%C5\%82u_ Praw_Cz\%C5\%82owieka_w_sprawie_Alicji_Tysi\%C4\%85c February 14, 2016). 
to "effect in man His loving design" . Conjugal love should involve responsible parenting. When abortion is accepted as a valid solution in marriage and family, the foundation, the entire basis on which the family is built comes down. Its meaning undergoes a tragic deformation. The place that, by its vocation, should be focused on the love and acceptance of life rejects love and chooses death.

Analyzing the problem of the killing of the unborn, we should realize that the promotion of abortion lies in the interest of abortion clinics, which earn huge amount of money on abortion ${ }^{5}$. It is not just about a fight for the idea which pro-abortionists believe is right. It is about a huge and gloomy business that profits from the killing of millions of human lives. The fight against the pro-abortion movement is not a struggle against some kind of a worldview or a way of thinking. It is a struggle against the real evil, acting here and now, the evil that strikes directly at a specific person.

\section{The Church's teaching on abortion}

The Church takes a clear position on abortion: "Since the first century the Church has affirmed the moral evil of every procured abortion. This teaching has not changed and remains unchangeable. Direct abortion, that is to say, abortion willed either as an end or a means, is gravely contrary to the moral law"6. This view is echoed in the whole teaching of the Church, which always emphasizes the Church's firmness of the once adopted view against abortion in all its aspects. Evangelium vitae, written in 1995 by John Paul II, a great defender of life, is an epochal encyclical which emphasizes the sanctity and inviolability of human life. It says that the inviolability of life, especially an innocent and defenseless life, is a moral truth derived from the

\footnotetext{
4 Paul VI, Humane vitae, no. 8.

5 It is worth reaching for the book "Blood Money" by Carol Everett, a former director and owner of the network of abortion clinics. Part of the book is available at: http://www.you.opoka.net.pl/pro_life/kliniki.htm (12.01.2016).

${ }^{6}$ Catechism of the Catholic Church, no. 2271.
} 
teaching of the Scripture ${ }^{7}$. It can be directly inferred from the fifth commandment, which simply says: "Thou shalt not kill".

In the apostolic exhortation Familiaris consortio, treating the situation of the family in the modern world, John Paul II draws attention to the signs of the degradation of the basic values and mentions "the plague of abortion" as one of these symptoms ${ }^{8}$. Indeed, it is the plague of our world, all the more dangerous in that it is becoming more and more acceptable to the general public and understood by many as one of the consequences of human freedom. However, we should be mindful that the Church is far more on the side of human freedom than pro-abortion organizations, since, in the teaching of the Church, the concept of freedom involves every person - a man and a woman, the healthy and the sick, a child and an old man, and finally, the weakest being, requiring a special care - an unborn human being with all their human dignity. No one except for God is a guarantee of true human freedom. In Familiaris consortio, pope John Paul II notices that the today's idea and experience of freedom is corrupted; it is oriented towards one's own selfish well-being and closed to the fulfillment of God's plan for marriage and family'. In the world where many concepts have already been distorted, e.g. the concept of freedom, the Church reminds us of the true meaning of these concepts, based on the word of God. And in this spirit, the Church must constantly remind us what marriage, family, love and responsibility are.

The inability to responsibly assume the role of the mother or father is probably rooted in the separation of the sexual act from its natural purpose, that is, the conception of a child. Spouses who close themselves to fertility, limiting their sexual sphere only to showing each other love and affection, to giving, or rather getting, a purely physical pleasure, may have difficulty in accepting the conception of a child, if they previously denied/rejected this aspect of the conjugal act from

\footnotetext{
7 Jan Paweł II, Evangelium vitae, no. 57.

8 Jan Paweł II, Familiaris consortio, no.6.

9 Ibid.
} 
their life. At this point comes up the question of the tasks that need to be faced by the Church and every Christian (and every man who sees the evil of abortion) in terms of defending the conceived life.

\section{Conclusions and pastoral indications}

Upholding the teaching of Christ, the Church should always openly defend life. Speaking of the "Church", I mean the whole community: both clergy and laity. It is the task of each of us to always and everywhere, especially where evil creeps into everyday life, abide in the truth and proclaim this truth to the world. And the truth is that God has given life to man and created him in His image. From this arises the unquestionable dignity of every human being and the fact that man does not dispose of his life as if he was its creator. We should make the world aware that the Decalogue contains everything that pertains to human rights; that it is the Gospel that provides the best advice on how to live in the society, family, and marriage. Nothing dignifies man more than his relationship with God. So when the life of a human being, the weakest, most fragile one and requiring a special care and attention, is compromised, every Christian has a duty to protest and stand in defense of his helpless brother or sister.

In the encyclical Evangelium vitae, pope John Paul II emphasizes that the task of every human being, and it is the task entrusted to them by God, is to defend, strengthen, love and respect life ${ }^{10}$.

First, the Church should educate a man and a woman who are entering into marriage what their mutual relationship is and what kind of responsibility it involves. It is worth quoting the words of John Paul II, who wrote that "conjugal love, while leading the spouses to the reciprocal 'knowledge' which makes them 'one flesh' does not end with the couple, because it makes them capable of the greatest possible gift, the gift by which they become cooperators with God for giving life to a new human person"11. The mutual love of the spouses

10 Jan Paweł II, Evangelium vitae, no. 42.

11 Jan Paweł II, Familiaris consortio, no. 14. 
is also the service to life. In the Letter to Families ${ }^{12}$, John Paul II noted that the birth of a child should deepen and enrich the conjugal communion between the parents. Spouses should always remember that God is the source of all parenting.

As John Paul II writes in the aforementioned Letter to the families, parenting itself is a proof of love, and a task assigned to both spouses. Christians do not remain passive in the face of the "civilization of death". There are pro-life organizations all over the world that conduct extensive activity to promote life. The international movement of $\mathrm{Hu}-$ man Life International undertakes a range of actions, raising people's awareness of the evil of abortion. HLI-Europa is a Polish foundation which belongs to the movement of Human Life International and is responsible for the region of Central and Eastern Europe. Evangelization in the spirit of the pope Paul VI's encyclical Humanae vitae and John Paul II's Evangelium vitae, the building of the civilization of life, protection of human life from conception to natural death, the defense of family values and Christian morality - these are the tasks of the Human Life International-Europe movement ${ }^{13}$. In many countries there are organized Marches for Life, during which crowds of people manifest their commitment to Christian values, relating to the dignity and inviolability of human life. In Poland, Fundusz Daru Życia prof. Włodzimierza Fijałkowskiego [Prof. Włodzimierz Fijałkowski's Fund of the Gift of Life] was created that donates all the received gifts to the defense of the unborn life. Also, Klub Przyjació 1 Ludzkiego Życia [Club of Friends of Human Life] contributes to the building of the civilization of love and life, and undertakes such actions as the online dissemination of prayer for the conversion of the opponents of life. Anyone can make a declaration to say such a prayer through the website of the Club.

As regards the position of the Church towards women who have had an abortion, considering the delicacy of the matter and the

\footnotetext{
12 http://www.opoka.org.pl/biblioteka/W/WP/jan_pawel_ii/listy/gratissimam. html (dostęp 10.03.2016).

13 http://www.hli.org.pl/xoops/modules/news/ (dostęp 12.02.2016).
} 
personal drama of each of these women, the Church should come forward to help them rebuild a normal life, having in mind the words addressed to these women by John Paul II in Evangelium vitae: "Do not give in to discouragement and do not lose hope. Try rather to understand what happened and face it honestly. If you have not already done so, give yourselves over with humility and trust to repentance. The Father of mercies is ready to give you his forgiveness and his peace in the Sacrament of Reconciliation. To the same Father and his mercy you can with sure hope entrust your child"14.

The women who are considering abortion because of a crisis situation and fear should, first of all, feel assured that they are not alone, and that if they decide to accept a tiny life, they will not remain alone, but will receive all the necessary support. Although abortion is evil, a sin against human life, we should look at the women who have had an abortion, or want it done, through the prism of mercy, understand that each of these sins is a personal drama, not judge them, but offer a wide-ranging help, even a simple conversation and assurance of our presence. Defending the endangered life of an unborn child, let everyone have in mind the words of our Savior "Truly, I tell you, whatever you did for one of the least of these brothers and sisters of mine, you did for me" (Mt 25, 40).

\section{Summary:}

As one of today's threats, abortion is both a sign of the times and a challenge for the Church and anyone who sees the evil of it. Every Christian is called to defend life, because life carries a unique dignity - each of us has been created by God out of love, and called to love. Today, when the topic of the human freedom to decide on everybody's own life often comes up in the discussion about abortion, it should be reminded that this freedom is the right of every human being, also the one who cannot speak on their own behalf.

14 Jan Paweł II, Evangelium vitae, nr 99. 


\section{Biogram:}

Zofia Kępińska-Walczak, MA in Theology, student of doctoral studies in pastoral theology at Cardinal Stefan Wyszyński University, graduate of the Institute of Knowledge of Culture (now the Institute of Dialogue of Culture and Religion) at Cardinal Stefan Wyszyński University in Warsaw, volunteer in the Association of Families and Carers of People with Down Syndrome "Bardziej Kochani", research interests: extraordinary ministry, Christian personalism, folk religiosity.

\section{Bibliography}

Jan Paweł II, Familiaris consortio, w: Jan Paweł II „Familiaris consortio”.

Tekst i komentarze, red. T. Styczeń, Lublin 1987.

Catechism of the Catholic Church, Rome 1992.

Paweł VI, Humanae vitae, Kraków 2003.

www.opoka.org.pl/biblioteka/W/WP/jan_pawel_ii/encykliki/evangelium_3.html\#m25.

www.opoka.org.pl/biblioteka/W/WP/jan_pawel_ii/listy/gratissimam.html; www. gosc.pl/doc/767838.Przyzwoity-sedzia-ze-Strasburga www.pl.wikipedia.org/wiki/Wyrok_Europejskiego_Trybuna\%C5\%82u_

Praw_Cz\%C5\%82owieka_w_sprawie_Alicji_Tysi\%C4\%85c 